\title{
Incidence and pattern of dental emergencies and their management during Covid-19 pandemic : An experience of Nepali dentists working during lock down
}

\author{
Dr Dashrath Kafleㄹ , Dr Rajeev K Mishra² \\ ${ }^{1}$ Associate Professor and Head, Department of Orthodontics, \\ Dhulikhel Hospital, Kathmandu University Teaching Hospital, Dhulikhel, Nepal. \\ ${ }^{2}$ Private Practice, Kathmandu, Nepal
}

Corresponding author:Dr. Dashrath Kafle,Email: dashrath07@yahoo.com

\section{ABSTRACT}

Introduction: Corona Virus Disease-2019(COVID-19) is highly contagious nature of disease which has spread all over the world in short span of time leading to significant number of death. WHO has declared pandemic and every nation is fighting with their all possible resources to control this disease. The impact of COVID-19 in dentistry is enormous. Most of the dental hospitals and clinic are providing emergency dental services only. So the aim of this research is to find out the nature of dental emergency during the initial month of lock down in Nepal. Additionally this research will try to find out the number of dental emergencies as well as perception of dentists on impact of Covid-19 on dentistry.

Materials and Method : A set of electronic questionnaires were sent to 150 Nepal Medical Council registered Nepalese dentists out of which only 122 dentists responded. A consent was obtained prior to collecting data for research purpose. All the quantitative answers were recorded in SPSS spread sheet where as qualitative data were collected in Microsoft word. Descriptive statistics were applied to explain the responses whenever applicable.

Result: Out of 122 respondents, maximum were from province 3 and 4 (50\% and $34 \%)$. Almost half of the respondents were general dental practioners and similar percentage of respondents were working at dental/medical colleges and government centers. $90 \%$ of the doctors had consulted patients during lock down period. Average 5-20 cases were seen during the lock down by majority of doctors. Nearly $58 \%$ of the doctors had done only virtual consultation and most common emergency was dental pain $(n=92)$ and swelling $(n=37)$. Majority of the respondents thought that standard of dental disinfection and sterilization will increase after pandemic, however most of the dentists thought they will be using PPE for dental work and cost of dental treatment will be increased because of the added cost of extra precaution. $90 \%$ of the dentists believed that they are going to change the way they practice dentistry after they reopen their clinic.

Conclusion: The most common type of dental emergency during lock down is dental pain ,swelling, dento-maxillofacial trauma and broken orthodontic appliances. Virtual dental consultation is gaining popularity among dentists in Nepal and Nepalese dentists are going to change the way of dental practice because of COVID-19

KEYWORDS: COVID-19, Dental Emergencies, Pain, Swelling, Tele dentistry

\section{INTRODUCTION}

Since the end of 2019, Covid-19 (Corona virus disease-2019) caused by novel corona virus has spread all over the world. In March 2020, WHO declared pandemic foreseeing the risk of this disease after which Whole world was moved into forced lock down'. This had impact on healthcare system including oral health. Most of the hospitals had to shut down the regular service and focus on Covid -19 and emergency cases only. Though massive effort has been laid globally, controlling Covid-19 seems to be a daunting task. So far 23 million people have been infected worldwide and death toll has reached to 803 thousands ${ }^{2}$. Covid-19 had substantial impact on dentistry globally3,4. In normal condition, except few emergencies, most of the dental treatment are regarded as elective. Emergency 
treatment is the condition which need to be addressed immediately and is usually life threatening. Dental problems are not considered life threatening as they can be waited for few hours till dental office opens in regular working hours. However, lock down during pandemic was completely different situation in which most of the dental hospitals and clinics were closed for weeks as per the directives of the governing bodies. Elective dental procedures were deferred for undefined period of time. Though the severity of problem might not be high at the onset, it might get worsen if timely intervention is not carried out. So in another way, with due course of time, non-emergent diseases may also turn into emergency problem.

During initial phase of pandemic, there were temporary cessation of dental treatment because of the uncertainty and lack of guideline ${ }^{5}$. Later emergency dental care was tried to manage via tele dentistry which was limited to prescription of analgesics and antibiotics to control the disease. During this period many countries endorsed telemedicine and tele prescription as valid way of patient consultation ${ }^{6-8}$. As most of the dental problem need intervention, dental problem were categorized into emergent, urgent and non-urgent and management guideline of each categories were recommended by different dental societies, associations and institutes including Nepal Dental Association(NDA) ${ }^{9-13}$. Unlike in normal condition, during pandemic, the lack of regular dental care is expected to increase the number of urgent dental cases significantly in due course of time ${ }^{14}$. In a recent survey done in United Kingdom (UK), it has been found that number of patients with space infections requiring incision and drainage has increased during lock down ${ }^{15}$. This has increased the number of patients requiring hospital admission as well.

There is no denial that dentistry is most vulnerable professionalong with ophthalmology and otolaryngology in relation with Covid-19 infection. Because of the highly contagious nature of disease and need of very close proximity of patient and doctor during procedure, there is high chance of disease transmissions to those professionals ${ }^{16,17}$. Most of the dental procedures need pressurized air and turbines which easily generate aerosol in the surrounding making dentistry even more vulnerable job. Undoubtedly transmission of Covid-19 is associated with droplets and aerosol ${ }^{18-21}$. This has led to decrease in number of dental procedures and has huge socioeconomic impact in long run ${ }^{22,23}$. Recently saliva has been shown to be the reservoir of corona virus which risks oral health care givers as one of the feared profession ${ }^{19,24,25}$. Because of these facts, number of patients seeking elective dental procedures might decrease in the future. There might be the trend to seek urgently needed dental treatment only.

Since the beginning of lock down, many healthcare workers have started giving virtual consultation from home and many offices have adopted work from home strategy as well ${ }^{26}$. There is always the concern over the tele dentistry as dentistry is procedure based profession. The dental emergencies are mainly pain, swelling, dentomaxillofacial trauma, pericoronitis etc ${ }^{27,28}$. It is found that $35 \%$ of the school going children suffer from dental pain which is the reason for absentism in school ${ }^{29}$. In a recent study done in China, it has been found that nature of emergency dental treatment has changed significantly compared to pre-covid period ${ }^{30}$. Similarly a study done at tertiary care centre in UK has found that $84 \%$ of the emergency dental patients during Covid-19 pandemic were related with dento alveolar surgery followed by trauma ${ }^{31}$. After the onset of Covid-19 pandemic, 90\% of the tertiary dental public hospitals in China were doing online consultation and $62 \%$ of them were doing free of $\operatorname{cost}^{32}$.The electronic consultation is one of the effective tool and has shown to prevent transmissionof Covid-1933. During such pandemic, utilization of social media and you tube channels to educate and consult disease is emphasized for helath workers ${ }^{34}$. Recently more user friendly applications such as whatsapp, viber, zoom are available for users which are gaining popularity for patient consultation. Such applications are popular in Nepal and are occasionally used for patient communication too. With this study, we aim to find the most commonly occurring dental emergencies during the initial 1 st month of lock down in Nepal. Apart from that this study will try to find out the rate of virtual consultation by dentists and their perception on impact of corona pandemic in dental practice.

\section{MATERIALS AND METHOD}

This was the cross sectional questionnaire based study carried out among the dentists of 5 provinces of Nepal. A prior consent was obtained before sending the questions. Nepal Medical Council registered dental surgeons willing to take part on the questionnaire based study were only enrolled into the study by sending google survey form. The identity of the respondents were kept not mandatory for the study. An electronic consent was 
obtained to use the data for the purpose of publication. Initially, request was sent to 150 dentists out of which only 122 dentists responded to the questions with response rate of $81 \%$. The quantitative data obtained were entered into SPSS(Version 20 IBM,USA) spread sheet for further descriptive analysis. The qualitative data were stored into Microsoft word form.

\section{RESULT}

Out of 122 participants, majority of the respondents were from province 3 and 4 (50\% and 34\%)(Figure 1). $62 \%$ of the respondents are general practioners working mostly at dental clinic(Figure 2,3 ). Nearly $50 \%$ of the participants practice dentistry at either medical/dental colleges or government hospitals (Figure 3 ). $90 \%$ of the respondents had consulted emergency dental patients during initial 1 st month of lock down out of which $58 \%$ had consulted only virtually (Figure 4). Majority of the doctors had consulted on an average 5-20 cases during initial month of lock down however some of the doctors had consulted up to 50 cases (Figure 5).

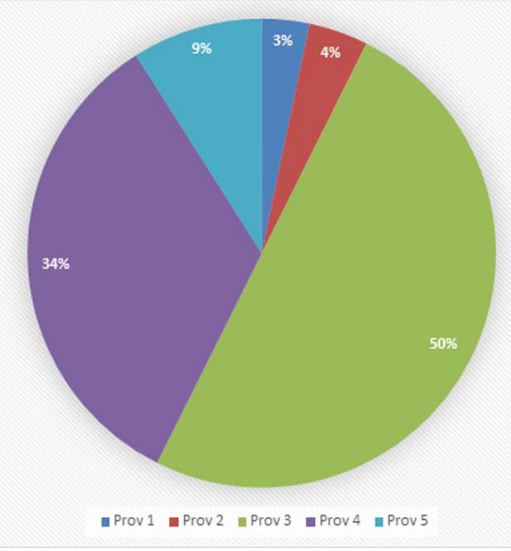

Fig 1: Number of respondents according to province

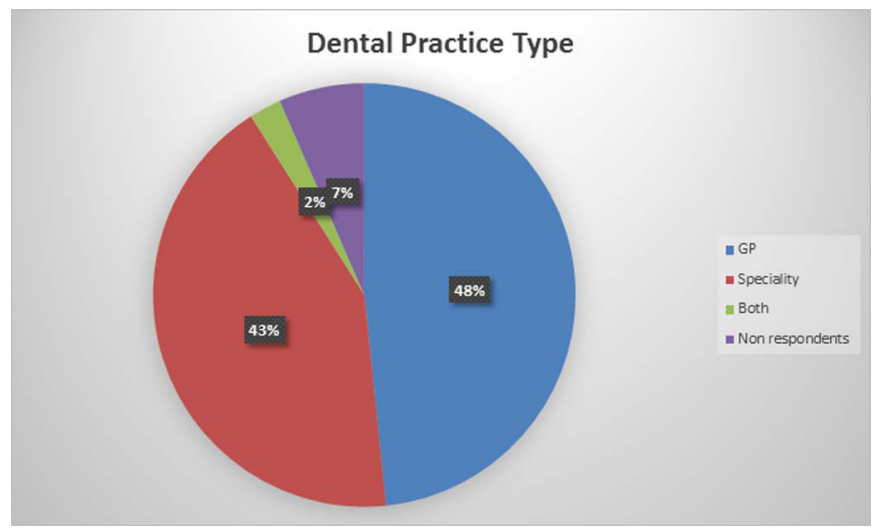

Fig 2: Dental Practice type

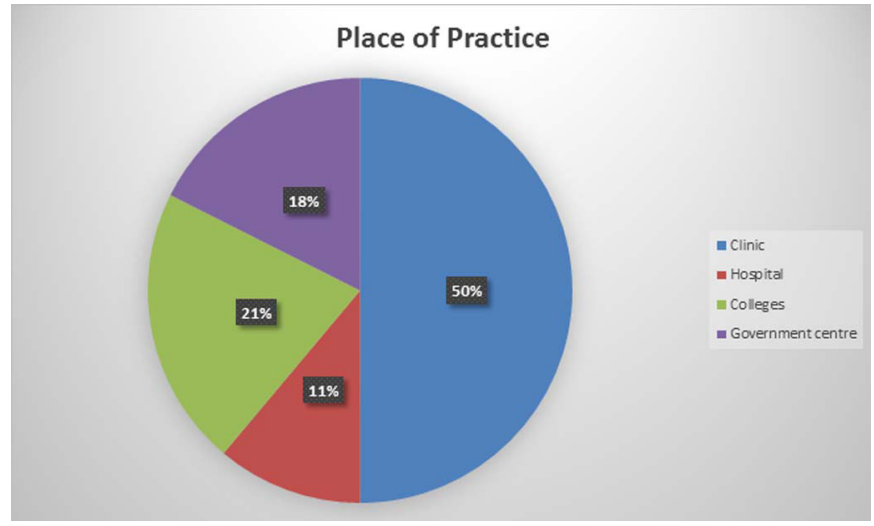

Fig 3: Place of Dental Practice

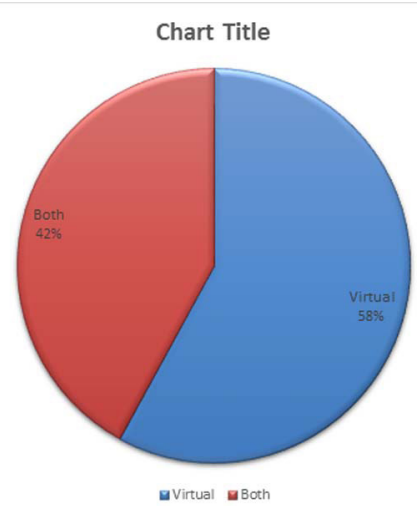

Fig 4: Type of Consultation during lock down

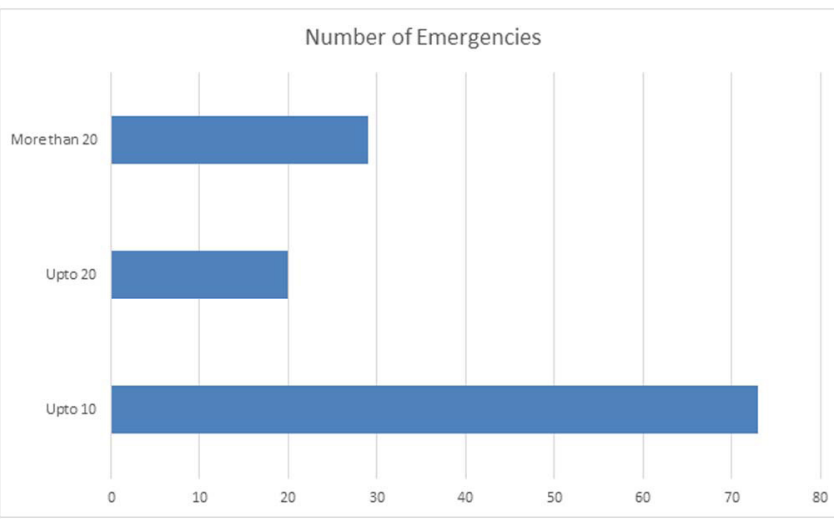

Fig 5: Number of dental emergencies

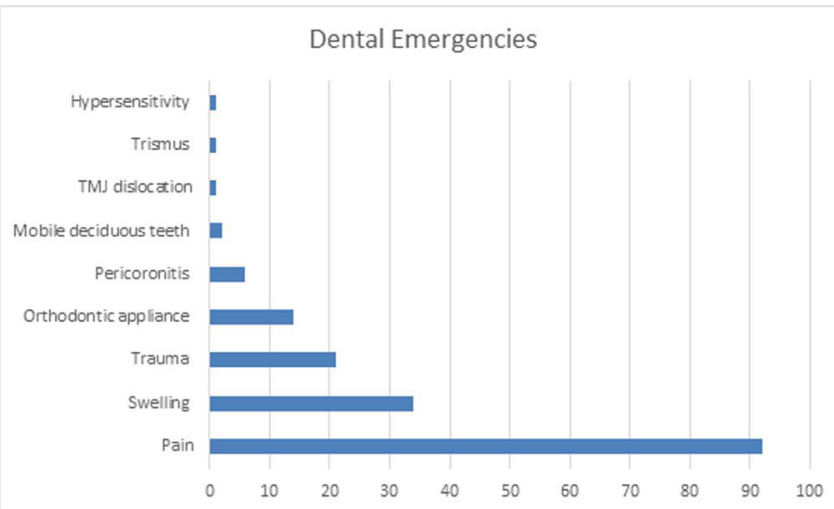

Fig 6: Type of dental emergencies 
Table 1: Impact of Covid-19 in dentistry

\begin{tabular}{|c|c|}
\hline $\begin{array}{l}\text { Increase the standard of disinfection and } \\
\text { sterilization than currently being followed }\end{array}$ & $56.9 \%$ \\
\hline $\begin{array}{l}\text { Increase the standard of disinfection and } \\
\text { sterilization than currently being followed } \\
\text { for the short term only. The standard will fall } \\
\text { again with time. }\end{array}$ & $35.3 \%$ \\
\hline $\begin{array}{l}\text { People will deem dental treatment a possible } \\
\text { risk factor for contracting Covid-19 and } \\
\text { hence only visit the dentist for emergency } \\
\text { or essential dental treatments only }\end{array}$ & $46.6 \%$ \\
\hline $\begin{array}{l}\text { Till definitive cure of Covid-19 is developed, } \\
\text { number of dental patients will decrease }\end{array}$ & $48.3 \%$ \\
\hline $\begin{array}{l}\text { Cost of dental treatment will increase } \\
\text { because of the added cost of precautionary } \\
\text { measures }\end{array}$ & $60.3 \%$ \\
\hline $\begin{array}{l}\text { There will be no change after the pandemic } \\
\text { is over }\end{array}$ & $5.2 \%$ \\
\hline $\begin{array}{l}\text { Dentists might need Personal Protective } \\
\text { Equiptments (PPE) for regular dental } \\
\text { procedures }\end{array}$ & $74.1 \%$ \\
\hline $\begin{array}{l}\text { Other } \\
\text { 1. Financial condition of private dental } \\
\text { practitioner will deteriorate, that may lead } \\
\text { to psychological problems along with no } \\
\text { change in sterilization and disinfection in } \\
\text { long terms unless more strict measures } \\
\text { and awareness increases among the } \\
\text { dentists as well as due to some sort of } \\
\text { issues with clinic owners who are not } \\
\text { related to dentistry. }\end{array}$ & $7 \%$ \\
\hline $\begin{array}{l}\text { 2. we should limit the per day patient } \\
\text { appointment so that we can give bit } \\
\text { more time for the sterilization and safety } \\
\text { procedure. }\end{array}$ & \\
\hline $\begin{array}{l}\text { 3. Dentists will be accepting emergency and } \\
\text { easy to do patients only. There will be } \\
\text { more extractions of teeth. }\end{array}$ & \\
\hline $\begin{array}{l}\text { 4. Since general public are not much } \\
\text { concerned or serious about the case } \\
\text { patients visiting clinics may not be } \\
\text { affected as it should. }\end{array}$ & \\
\hline $\begin{array}{l}\text { 5. For only physical consultation (check ups) } \\
\text { need N-95 mask over surgical mask and } \\
\text { for procedures PPE must till vaccination } \\
\text { or definitive cure is found }\end{array}$ & \\
\hline $\begin{array}{l}\text { 6. Negative pressure air purifier installation } \\
\text { in dental clinics and facilities is advisable }\end{array}$ & \\
\hline $\begin{array}{l}\text { 7. The public is not so aware so there will } \\
\text { more number of patients once it is over }\end{array}$ & \\
\hline
\end{tabular}

\section{DISCUSSION}

Our survey has revealed that the most common type of dental emergency during pandemic lock down was pain followed by swelling. Those two conditions are the common causes of dental emergencies during normal situation as well. In our study more than $75 \%$ of the doctors who consulted patients during pandemic were for dental pain. The second most common reason for consultation was swelling. The cause of acute swelling is infection in and around the tooth and its surrounding structure. In our study, the swelling was associated with dental infection such as pulpitis, dento alveolar abccess, trauma, periodontal and gingival infection and peri coronal infection. A recent study by Guo et al from Peking, China has found that nature of dental emergency cases has changed after pandemic. They compared the nature of emergency dental cases before and after Covid-19 pandemic. They found that proportion of dental infection had increased from $51 \%$ to $71 \%$ whereas the dental trauma decreased from $14 \%$ to $10 \%{ }^{30}$. This might be because of the reduced number of vehicles in the street. A similar study done at tertiary care center in UK has found $63 \%$ of the patient presenting for dental emergencies are of pain secondary to acute pulpitis followed by odontogenic infection and trauma. Out those acute pulpitis cases, only $9 \%$ were categorized as emergency cases whereas $74 \%$ were categorized as urgent. Another study done by Long and Crosar has also led to similar findings as with previous studies ${ }^{35}$. Additionally they have also noted that the daily emergency dental care patients decreased however patients requiring admission because of infection rose from 35 to $80 \%^{35}$. This indicates that the behavior of general people seeking routine dental care has decreased. In contrast to finding of Long and Crosar, a recent study has found that orthodontic patients want to continue their treatment despite the fear of Covid-1 $19^{36}$. In our study nearly $14 \%$ of the emergency cases are related to orthodontic treatment therapy. There are number of non-life threatening orthodontic emergencies which can be easily managed by tele orthodontics ${ }^{37-39}$. In our study almost $60 \%$ of the dentists had done virtual consultation which is similar to the study done by Stangvaltaite et al from Norway. ${ }^{40}$ Tele dentistry/ medicine though advocated many years back, has now gained the popularity after Covid-19 pandemic ${ }^{41-45}$. A recent study has shown that even without radiographs, tele dentistry can reliably diagnose dental caries ${ }^{46}$. The majority number of respondents in our study think that the standard of dental sterilization and disinfection will 
increase because of the Covid-19 pandemic. This can be the mandatory opportunity for dentists to upgrade their practice in the interest of patient and operator safety. Similarly, most of the respondents emphasize on the use of PPE for patient care. It is very important to know that proper donning and doffing of PPE should be carried out to prevent cross infection at dental practice ${ }^{5,9,12,47}$. Because of the pandemic, there is global shortage of PPEs and health care workers are found to work in substandard safety measures which increases the risk of disease transmission. Reduced number of work and working with lack of proper protection is definitely going to impact the psychological wellbeing of dentists ${ }^{48}$. Moreover the dentists are the most vulnerable healthcare workers and this disease should not be taken lightly as based on the experience from other countries ${ }^{49}$. In our survey there are very important points which are raised by the respondents. They have emphasized the need of reducing number patients and installing negative air pressure, high vacuum suction and filter in working areas. These points are valid and evidence based too ${ }^{50,51}$. A recent multinational study has found that dentists have good knowledge and practice behavior to combat Covid-19 disease ${ }^{52}$. Our survey also shows that dentists working in Nepal have good knowledge on current evidence on Covid-19 management.

\section{CONCLUSION}

The most common dental emergency during lockdown period is dental pain followed by swelling ,dentomaxillofacial trauma and orthodontic appliance breakage. Tele dentistry is emerging as one of the modes of patient consultation in Nepal. Majority of the doctors think that they are going to change the way they practice dentistry in future.

\section{REFERENCES}

1. www.who.int/covid-19/information

2. https://www.worldometers.info/coronavirus

3. Passarelli PC, Rella E, Manicone PF, Garcia-Godoy F, D'Addona A. The impact of the COVID-19 infection in dentistry. Experimental biology and medicine. 2020;245(11):940-4.

4. https://www.ada.org/en/science-research/health-policy-institute/covid-19-dentists-economic-impact

5. Grossman S, Sandhu P, Sproat C, Patel V. Provision of dental services at a single institution in the UK's epicentre during the COVID-19 pandemic. British dental journal. 2020;228(12):964-70.

6. Monaghesh E, Hajizadeh A. The role of telehealth during COVID-19 outbreak: a systematic review based on current evidence. BMC public health. 2020;20(1):1193.

7. Mahajan V, Singh T, Azad C. Using Telemedicine During the COVID-19 Pandemic. Indian Pediatrics. 2020;57(7):658-61.

8. Kaplan B. REVISTING HEALTH INFORMATION TECHNOLOGY ETHICAL, LEGAL, and SOCIAL ISSUES and EVALUATION: TELEHEALTH/ TELEMEDICINE and COVID-19. International Journal of Medical Informatics. 2020:104239.

9. Gugnani N, Gugnani S. Safety protocols for dental practices in the COVID-19 era. Evidence-based dentistry. 2020;21(2):56-7.

10. Peditto M, Scapellato S, Marciano A, Costa P, Oteri G. Dentistry during the COVID-19 Epidemic: An Italian Workflow for the Management of Dental Practice. International journal of environmental research and public health. 2020;17(9).

11. https://www.cdc.gov/coronavirus/2019-ncov/hcp/dental-settings.html.

12. Alharbi A, Alharbi S, Alqaidi S. Guidelines for dental care provision during the COVID-19 pandemic. The Saudi dental journal. 2020.

13. https://nda.org.np/erp//UploadedFiles/Doclmages/5.pdf.

14. Brkic H. Dental medicine and COVID-19 pandemic. Acta stomatologica Croatica. 2020;54(2):118-20.

15. Politi I, McParland E, Smith R, Crummey S, Fan K. The impact of COVID-19 on cervicofacial infection of dental aetiology. The British journal of oral \& maxillofacial surgery. 2020.

16. Naqvi K, Mubeen SM, Ali Shah SM. Challenges in providing oral and dental health services in COVID-19 pandemic. JPMA The Journal of the Pakistan Medical Association. 2020;70(Suppl 3)(5):S113-S7.

17. Odeh ND, Babkair H, Abu-Hammad S, Borzangy S, Abu-Hammad A, Abu-Hammad O. COVID-19: Present and Future Challenges for Dental Practice. International journal of environmental research and public health. 2020;17(9).

18. Adhikari SP, Meng S, Wu Y-J, Mao Y-P, Ye R-X, Wang Q-Z, et al. Epidemiology, causes, clinical manifestation and diagnosis, prevention and control of coronavirus disease (COVID-19) during the early outbreak period: a scoping review. Infectious Diseases of Poverty. 2020;9(1):29.

19. Baghizadeh Fini M. Oral saliva and COVID-19. Oral oncology. 2020;108:104821.

20. Miller R, Englund K. Transmission and risk factors of OF COVID-19. Cleveland Clinic journal of medicine. 2020.

21. Sapkota D, Thapa SB, Hasseus B, Jensen JL. Saliva testing for COVID-19? British dental journal. 2020;228(9):658-9. 
22. Chamorro-Petronacci C, Martin Carreras-Presas C, Sanz-Marchena A, M AR-F, Maria Suarez-Quintanilla J, Rivas-Mundina B, et al. Assessment of the Economic and Health-Care Impact of COVID-19 (SARS-CoV-2) on Public and Private Dental Surgeries in Spain: A Pilot Study. International journal of environmental research and public health. 2020;17(14).

23. Farooq I, Ali S. COVID-19 outbreak and its monetary implications for dental practices, hospitals and healthcare workers. Postgraduate medical journal. 2020.

24. Alizargar J, Etemadi Sh M, Aghamohammadi M, Hatefi S. Saliva samples as an alternative for novel coronavirus (COVID-19) diagnosis. Journal of the Formosan Medical Association = Taiwan yi zhi. 2020.

25. Azzi L, Carcano G, Gianfagna F, Grossi P, Gasperina DD, Genoni A, et al. Saliva is a reliable tool to detect SARS-CoV-2. The Journal of infection. 2020.

26. AIShaya MS, Assery MK, Pani SC. Reliability of mobile phone teledentistry in dental diagnosis and treatment planning in mixed dentition. 2020;26(1-2):45-52.

27. Nguyen DH, Martin JT. Common dental infections in the primary care setting. American family physician. 2008;77(6):797-802.

28. Douglass AB, Douglass JM. Common dental emergencies. American family physician. 2003;67(3):511-6.

29. Kumar YS, Acharya S, Pentapati KC. Prevalence of dental pain and its relationship to caries experience in school children of Udupi district. European archives of paediatric dentistry : official journal of the European Academy of Paediatric Dentistry. 2014;15(6):371-5.

30. Guo H, Zhou Y, Liu X, Tan J. The impact of the COVID-19 epidemic on the utilization of emergency dental services. Journal of dental sciences. 2020.

31. Pajpani M, Patel K, Bendkowski A, Stenhouse P. Rapid response: activity from a hospital based Urgent Dental Care Centre during the COVID-19 pandemic. The British journal of oral \& maxillofacial surgery. 2020.

32. Yang $Y$, Zhou $Y$, Liu $X$, Tan J. Health services provision of 48 public tertiary dental hospitals during the COVID-19 epidemic in China. Clinical oral investigations. 2020;24(5):1861-4.

33. Gong K, XuZ. Internet Hospitals Help Prevent and Control the Epidemic of COVID-19 in China: Multicenter User Profiling Study. 2020;22(4):e18908.

34. Yuce MO, Adali E, Kanmaz B. An analysis of YouTube videos as educational resources for dental practitioners to prevent the spread of COVID-19. Irish journal of medical science. 2020.

35. Long L, Corsar K. The COVID-19 effect: number of patients presenting to The Mid Yorkshire Hospitals OMFS team with dental infections before and during The COVID-19 outbreak. The British journal of oral \& maxillofacial surgery. 2020;58(6):713-4.

36. Peloso RM, Pini NIP, Sundfeld Neto D, Mori AA, Oliveira RCG, Valarelli FP, et al. How does the quarantine resulting from CoVID-19 impact dental appointments and patient anxiety levels? Brazilian oral research. 2020;34:e84.

37. Saltaji H, Sharaf KA. COVID-19 and orthodontics-A call for action. American journal of orthodontics and dentofacial orthopedics : official publication of the American Association of Orthodontists, its constituent societies, and the American Board of Orthodontics. 2020;158(1):12-3.

38. Saccomanno S, Quinzi V, Sarhan S, Lagana D, Marzo G. Perspectives of tele-orthodontics in the COVID-19 emergency and as a future tool in daily practice. European journal of paediatric dentistry. 2020;21(2):157-62.

39. Artese F. Covid-19: The aftermath for orthodontics. Dental press journal of orthodontics. 2020;25(2):7-8.

40. Stangvaltaite-Mouhat L, Uhlen MM, Skudutyte-Rysstad R, Szyszko Hovden EA, Shabestari M, Ansteinsson VE. Dental Health Services Response to COVID-19 in Norway. International journal of environmental research and public health. 2020;17(16).

41. Chopra SS, Sahoo NK. Protocol for teledentistry during COVID-19 in Armed Forces dental establishments. Medical journal, Armed Forces India. 2020;76(3):356-9.

42. Ghai S. Teledentistry during COVID-19 pandemic. Diabetes \& metabolic syndrome. 2020;14(5):933-5.

43. Giudice A, Barone S, Muraca D, Averta F, Diodati F, Antonelli A, et al. Can Teledentistry Improve the Monitoring of Patients during the Covid-19 Dissemination? A Descriptive Pilot Study. International journal of environmental research and public health. 2020;17(10).

44. Martins MD, Carrard VC, Dos Santos CM, Hugo FN. COVID-19-Are telehealth and tele-education the answers to keep the ball rolling in Dentistry? Oral diseases. 2020.

45. Maspero C, Abate A, Cavagnetto D, El Morsi M, Fama A, Farronato M. Available Technologies, Applications and Benefits of Teleorthodontics. A Literature Review and Possible Applications during the COVID-19 Pandemic. Journal of clinical medicine. 2020;9(6).

46. Meng L, Hua F. Coronavirus Disease 2019 (COVID-19): Emerging and Future Challenges for Dental and Oral Medicine. 2020;99(5):481-7.

47. Gurzawska-Comis K, Becker K, Brunello G, Gurzawska A, Schwarz F. Recommendations for Dental Care during COVID-19 Pandemic. Journal of clinical medicine. 2020;9(6).

48. Consolo U, Bellini P, Bencivenni D, lani C, Checchi V. Epidemiological Aspects and Psychological Reactions to COVID-19 of Dental Practitioners in the Northern Italy Districts of Modena and Reggio Emilia. International journal of environmental research and public health. 2020;17(10).

49. Izzetti R, Nisi M, Gabriele M, Graziani F. COVID-19 Transmission in Dental Practice: Brief Review of Preventive Measures in Italy. Journal of dental research. 2020;99(9):1030-8.

50. Convissar D, Chang CY, Choi WE, Chang MG, Bittner EA. The Vacuum Assisted Negative Pressure Isolation Hood (VANISH) System: Novel Application of the Stryker Neptune ${ }^{\mathrm{TM}}$ Suction Machine to Create COVID-19 Negative Pressure Isolation Environments. Cureus. 2020;12(5):e8126.

51. Hellman S, Chen GH, Irie T. Rapid clearing of aerosol in an intubation box by vacuum filtration. British journal of anaesthesia. 2020.

52. Kamate SK, Sharma S, Thakar S, Srivastava D, Sengupta K, Hadi AJ, et al. Assessing Knowledge, Attitudes and Practices of dental practitioners regarding the COVID-19 pandemic: A multinational study. Dental and medical problems. 2020;57(1):11-7. 